\title{
Radon Concentrations in Various Indoor Environments and Effective Doses to Inhabitants in Korea
}

\author{
Cheol Min Lee \\ Institute of Environmental and Industrial Medicine, HanyangUniveristy \\ 17 Haengdang-dong, Seongdong-gu, Seoul 133-791, South Korea \\ Tel: 82-10-2074-0409Ｅ-mail: spica@hanyang.ac.kr \\ In Suk Sim \\ Institute of Environmental and Industrial Medicine, HanyangUniveristy \\ 17 Haengdang-dong, Seongdong-gu, Seoul 133-791, South Korea \\ Tel: 82-10-7109-5239Ｅ-mail: arielldlstur@hanyang.ac.kr \\ Yong Sung Cho \\ Institute of Environmental and Industrial Medicine, HanyangUniveristy \\ 17 Haengdang-dong, Seongdong-gu, Seoul 133-791, South Korea \\ Tel: 82-10-5488-3574Ｅ-mail: p5010@hanyang.ac.kr
}

Gee Yong Park

Institute of Environmental and Industrial Medicine, HanyangUniveristy

17 Haengdang-dong, Seongdong-gu, Seoul 133-791, South Korea

Tel. 82-10-5479-0494Ｅ-mail: geeyong0494@gmail.com

Yoon Shin Kim

Institute of Environmental and Industrial Medicine, HanyangUniveristy

17 Haengdang-dong, Seongdong-gu, Seoul 133-791, South Korea

Tel: 82-11-268-6747Ｅ-mail: yooushin@hanyang.ac.kr

Sun Ju Nam Goung

Institute of Environmental and Industrial Medicine, HanyangUniveristy

17 Haengdang-dong, Seongdong-gu, Seoul 133-791, South Korea

Tel: 82-10-3318-0536 E-mail: happying2@hanmail.net

Young Kyung Joo

Institute of Environmental and Industrial Medicine, HanyangUniveristy

17 Haengdang-dong, Seongdong-gu, Seoul 133-791, South Korea

Tel: 82-10-8956-3445Ｅ-mail: wndudrud@nate.com

Received: August 31, 2011

Accepted: September 16, $2011 \quad$ Published: January 1, 2012

doi:10.5539/ep.v1n1p55

URL: http://dx.doi.org/10.5539/ep.v1n1p55 


\begin{abstract}
The objective of this study is to offer basic scientific data to support policy decision-making for the improved control of radon and natural radiation gases in Korea, and to provide baseline data on radon for use in cooperative international research. Therefore, this study collected and re-analyzed articles on radon exposure in various indoor environments in Korea that were published in environmental journals since 1980, and estimated the annual exposure and effective radon doses for inhabitants. Among the various indoor environments, the highest pooled average radon concentration of $50.17 \pm 4.08 \mathrm{~Bq} / \mathrm{m}^{3}\left(95 \%\right.$ CI: $\left.42.17-58.17 \mathrm{~Bq} / \mathrm{m}^{3}\right)$ was found in homes. All of the pooled average radon concentrations estimated in this study were lower than the guideline concentration $\left(148 \mathrm{~Bq} / \mathrm{m}^{3}\right)$ recommended by the U.S. EPA and the Korean Ministry of Environment. The annual effective dose received by inhabitants in various indoor environments was estimated to be $1.071 \mathrm{mSv} / \mathrm{yr}$. This is comparable to the annual radon exposure effective dose $(1.0 \mathrm{mSv} / \mathrm{yr})$ estimated by UNSCEAR.
\end{abstract}

Keywords: Radon, Various indoor environments, Pooled concentration, Effective dose

\title{
1. Introduction
}

Since the 1970s, buildings in all kinds of industrial fields have been insulated tightly to improve heat efficiency and equipped with energy-saving equipment; and indoor air quality, typical of indoor environmental problems, has been deteriorating inside those buildings. Deterioration of indoor air quality shall be defined as pollution of indoor air by all kinds of pollutants emitted into the air originating from various human activities and natural sources such as soil, etc. (Wood, 1991). The increased insulation and tight sealing within buildings, which improves energy efficiency, is thought to cause increased pollutant concentrations in indoor air due to the longer duration of hazardous air pollutants remaining inside.

Today, most people stay indoors for more than $90 \%$ of their day (Robinson \& Nelson, 1995; The Ministry of Environment, Korea, 2001). Considering the results of recent studies showing that the indoor concentrations of the main hazardous air pollutants are higher than those outdoors (Kim \& Jeong, 2006; Lee \& Chang, 2000), it is obvious that these pollutants may have a negative effect on health over a long period, though they are not so bad as to threaten residents' lives. Therefore, it is considered important that, in a modern society, urgent consideration be given to preparing measures and establishing an improvement and control plan to prevent deterioration of indoor air quality in the context of environmental conservation.

In order to protect the public health, the Korean Ministry of Environment has acknowledged the importance of maintaining and controlling indoor air quality, and has enacted, promulgated and enforced the law for indoor air quality control in public facilities since May 2004. This law, which applies to public facilities and newly-built apartment houses, limits the levels of five potentially dangerous pollutants with a mandatory standard $\left(\mathrm{PM}_{10}\right.$, $\mathrm{CO}_{2}$, formaldehyde, total airborne microbes, and $\mathrm{CO}$ ), and a further five pollutants with a recommended standard $\left(\mathrm{NO}_{2}, \mathrm{Rn}\right.$, TVOCs, asbestos, ozone) for 17 groups of public. Most of these pollutants with mandatory or recommended standards are generated from human activities, but radon is a naturally occurring radioactive material which mainly originates from soil. Thus, special attention should be paid to monitoring radon levels over other pollutants with mandatory and recommended standards.

Radon, a radioactive gas from the uranium decay chain, has been known to be the highest source of radiation exposure in human beings (Fovt, 1999; UNSCEAR, 2000), and previous studies have reported that exposure to high radon concentrations causes lung cancer (Miles, 1988; Yang et al., 1999). In 1998, the NAS (National Academy of Sciences) and the U.S. EPA (Environmental Protection Agency) reported that 15,000-25,000 deaths from lung cancer every year are estimated to be due to radon exposure (NRC, 1999).

Currently, the ICRP (International Commission on Radiological Protection) has decided upon a radon action level of 200-600 Bq/ $\mathrm{m}^{3}$ (ICRP, 1994), and the NRPB (National Radiological Protection Board, U.K.) has recommended a threshold limit value of $200 \mathrm{~Bq} / \mathrm{m}^{3}$ to be maintained within a house(NRPB, 1990). Regarding the hazard posed to humans by radon in the environment, the EPA reported that if a human body is exposed to radon levels of $4 \mathrm{pCi} / 1\left(148 \mathrm{~Bq} / \mathrm{m}^{3}\right)$, the probability of developing lung cancer is 13-50 persons per 1,000. Furthermore, exposure to a radon level of $20 \mathrm{pCi} / 1\left(740 \mathrm{~Bq} / \mathrm{m}^{3}\right)$, is as hazardous as smoking a pack of cigarettes a day. Therefore, the EPA has recommended a radon action level of lower than $4 \mathrm{pCi} / 1\left(148 \mathrm{~Bq} / \mathrm{m}^{3}\right)$ for the air within a residence (EPA, 1986). Many advanced countries have actively performed local and international studies on actual conditions, assessments of health hazards, and epidemiological research to set up and maintain radon action levels. But in Korea, the Ministry of Environment has recently recommended that EPA's radon action level be maintained in various indoor environments as part of the law on indoor air quality control for public facilities. If one considers that poor studies have been performed on radon concentrations under actual conditions and on the assessment of radon's health hazards in the domestic indoor environment so far, this level 
should not be regarded as reflecting actual domestic environmental characteristics. Therefore, many studies on actual conditions are absolutely required to provide baseline data for re-establishing the appropriate standard level for the domestic environment, and for performing epidemiological research to examine physical disorders attributable to radon.

This study has collected the results from studies on radon concentrations under actual conditions that were executed in various indoor environments in Korea. By using the meta-analysis method to re-analyze the collected data, it reports the pooled average concentration in the air in various indoor environments. Also, it has calculated the exposure and effective doses of radon that occupants in each indoor surrounding environment inhale. Therefore, it is suggested that the results of this study be applied as basic data in establishing the Korean indoor air quality policy and control plan against radon and natural radioactive material. Furthermore, it is suggested that these results be used in establishing the foundation to participate in international joint research.

\section{Materials and Methods}

\subsection{Data Collection}

To collect past domestic research data related to radon concentrations in various indoor environments, the following literature search and selection conditions were set up using the domestic electronic journal search and the meta search engines from the academic database (http://library.hanyang.ac.kr/dlsearch/TGUI /Hanyang/Main.asp) supported by the Baeknam Academic Information Center of Hanyang University. Only suitable research articles were chosen to set up the database.

The first literature search condition chosen to execute the study was that the engines of the domestic electronic journal search and the meta search be used in searching the Baeknam academic database. Second, the key words were those that indicate various indoor environments such as "the indoor environment", "public facilities", and "indoor air quality", and the word "radon". Third, only articles published in completely domestic environmentally-related journals were searched. The first literature selection condition was to choose only research articles published in Korean journals since the 1980s. Second, after checking the content of a chosen research article, only those articles that conformed to the study's subject, radon pollution in the indoor air and its influence on the human body, were selected.

\subsection{Data Arrangement and Analysis}

Based on the established database, the pooled average radon concentration measured in various indoor environments was calculated by the inverse-variance-weighted average method, and this pooled average concentration was used as the exposure concentration when calculating the inhaled radon exposure and effective doses for occupants in various indoor environments.

For the calculation of pooled average radon concentrations in various indoor environments, the following selection condition was established; "first, after classifying research results that used the same measurement and analysis methods, only the research results that examined the radon concentration using a solid-state track detector were selected. And second, only the research results that were shown with the concentration and range (the standard deviation, range, variance, maximum and minimum) of radon per indoor environment were selected." And only those results suitable to the conditions were applied.

The reverse-variance-weighted average method used in the study is preferred to calculate the pooled average, considering the size of each study (the number of data points, etc.), from the selected studies' results (average concentrations) as a way for the analysis of effect-magnitude measures of the meta analysis (Son, 1998). In this method, the estimate of a pooled average is assumed to be approximately normally distributed. That is,

$$
\overline{\theta_{i}}=N\left(\theta_{i}, \omega_{i}^{-1}\right), i=1,2, \cdots, k
$$

$\omega_{\mathrm{i}}$ is equal to the inverse variance of $\overline{\theta_{i}}$, that is, $\omega_{i}=\frac{1}{\operatorname{var}(\bar{\theta})}$. Also, the study of a component $\kappa$ is independent from others. Thus, if the pooled average's estimate is assumed to be $\theta_{1}=\theta_{2}=\cdots=\theta_{\kappa}=\theta$, its distribution is approximately normally distributed as follows;

$$
\sum \overline{\theta_{i}} \omega_{i} \sim N\left(\theta \sum \omega_{i}, \sum \omega_{i}\right)
$$

Thus, 


$$
\bar{\theta}=\frac{\sum_{i=1}^{k} \overline{\theta_{i}} \omega_{i}}{\sum_{i=1}^{k} \omega_{i}}, \text { that is, } \operatorname{Var}(\bar{\theta})=\frac{1}{\sum_{i=1}^{k} \omega_{i}}
$$

By using $\overline{\theta_{i}}$ to be approximately normally distributed, the $95 \%$ confidence interval of $\overline{\theta_{i}}$ is calculated using the following equation;

$$
\bar{\theta} \pm 1.96 \sqrt{\frac{1}{\sum_{i=1}^{k} \omega_{i}}}
$$

where $\omega_{\mathrm{i}}$ works as a weight in pooling several study results.

\subsection{Data Calculation}

The radon radiation exposure dose was expressed as WL (working level: if the radon concentration in the air is $100 \mathrm{pCi} / 1$, it is the total energy of $\alpha$ radiation radiated when radon and radon progeny reach radioactive equilibrium) that is the concentration measurement unit of radon progeny, based on the pooled average concentration of radon, which was calculated by using the reverse-variance-weighted method to expect the exposure dose to radon by various indoor environments (Bodansky, 1989).

$$
W L=F t \times \frac{C_{R n}}{100}
$$

Ft: the value of the equilibrium factor between indoor radon and radon progeny.

$\mathrm{C}_{\mathrm{Rn}}$ : the mean concentration of radon.

The study used 0.4 as the ICRP recommended value of the equilibrium factor between indoor radon and radon progeny (ICRP, 1994). And the cumulative exposure dose for 170 hours, which is the exposure time of a month at a concentration atmosphere of $1 \mathrm{WL}$, was converted into $1 \mathrm{WLM}$ (working level month).

$$
W L M=W L \times \frac{\text { Exposure time }}{170}
$$

Exposure time: the time an occupant remained in each of the various indoor environments

$$
W L M / y r=W L M \times 12 \text { Months } / y r
$$

The value of WLM was converted into WLM/yr, the annual cumulative exposure and effective dose attributable to radon were calculated for each indoor environment and the total indoor environment by using the dose conversion coefficient $\left(9 \mathrm{nSv} / \mathrm{Bqhm}^{-3}\right)$, recommended by UNSCEAR (UNSCEAR, 2000; 1993). Indoor time of occupants within the various indoor environments came from a Korean Ministry of Environment study describing the daily activities, their sites and the duration of activities at each site for 838 adults throughout the country (the Ministry of Environment, Korea, 2001).

\section{Results}

\subsection{Research Related to Radon Concentrations in Korea}

Since 1980, a total of 37 articles have been published as radon-related studies in domestic environmental journals. Of these articles, 17 were determined to conform to the requirements of this study. Table 1 is the summary of these 17 study results. Figure 1 shows how frequently studies on indoor radon concentrations were performed for each of the various indoor environments. Houses (including 3 apartments) were found to be studied most frequently with 12 cases $(24.5 \%)$, next were subway stations with 6 cases $(12.2 \%)$, and schools and hospitals with 4 cases $(8.2 \%)$. Research on other public facilities has been executed since 2003.

It is known that the radon concentration in indoor air is greatly influenced by the radon concentration in soil and construction materials (Durrani, 1999). For this reason, Anastasiou et al. (2003) reported that a basement and underground space directly in contact with soil show higher radon concentrations in the airthan other spaces. Li et al. (2005) suggested that indoor ventilation is one of the major factors that greatly influence the radon concentration in indoor air. Other major factors responsible for the radon concentration in indoor air are the 
building's age, height, and indoor temperature and humidity (Barros-Dios et al., 2007; Frederick \& Paul, 2001). Similarly, it is clear that the radon concentration in indoor air is greatly affected by the surrounding physical and chemical characteristics. Foreign countries have tried to examine these influential factors and to establish a plan to lower radon concentrations by controlling them. Some research in Korea is also known to have been carried out by inclusion in the range of studies on actual conditions to examine the effects of these influential factors. The representative studies examining the effects of these factors include evaluations of the difference between radon concentrations above and below ground level inside a building due to the different quality of soils in an examined area, the relation between indoor temperature/humidity and the radon concentration, the relation between indoor air pollutants' (e.g. fine particles) concentrations and the radon concentration, the different radon concentrations by ventilation volume (in an energy-efficient and non-energy-efficient building), and the influence of a building's construction date on radon concentrations. In addition, a study was performed to examine the level to which the radon concentration within underground water influences that in the indoor air.

\subsection{Pooled Average Radon Concentration in Each Indoor Environment}

To calculate the pooled average concentration of radon in the air in each indoor environment, this study selected only research results that were examined with a sold-state track detector (CR-39 film) from among those that investigated the radon concentration in the indoor air in Korea, and calculated the pooled average radon concentration in the air in each indoor environment (Figure 2).

The house was found to have the highest concentration with $50.17 \pm 4.08 \mathrm{~Bq} / \mathrm{m}^{3}(95 \%$ confidence interval: $42.17 \sim 58.17 \mathrm{~Bq} / \mathrm{m}^{3}$ ) among pooled average radon concentrations in various indoor environments. This value is less than half the concentration of $148 \mathrm{~Bq} / \mathrm{m}^{3}$ recommended by the Korean law for indoor air quality control in public facilities and the U.S. EPA, and it shows radon to be distributed at very low concentrations in the air in domestic indoor environments.

Figure 3 shows the pooled average radon concentration in the air of the ground and underground levels of buildings, which either are or are not equipped with tight-sealing and energy-saving equipment to improve energy efficiency. The pooled average radon concentration in the underground space of a building was calculated to be $32.00 \pm 4.08 \mathrm{~Bq} / \mathrm{m}^{3}\left(95 \%\right.$ confidence interval: $24.00 \sim 40.00 \mathrm{~Bq} / \mathrm{m}^{3}$ ) and that in its ground space to be $33.38 \pm 3.54 \mathrm{~Bq} / \mathrm{m}^{3}\left(95 \%\right.$ confidence interval: $\left.26.45 \sim 40.30 \mathrm{~Bq} / \mathrm{m}^{3}\right)$. This result shows similar concentrations in the ground and underground levels. Pooled average radon concentrations of a building equipped with energy-saving equipment and a building not so equipped were $90.00 \pm 14.14 \mathrm{~Bq} / \mathrm{m}^{3}$ and $60.50 \pm$ $7.07 \mathrm{~Bq} / \mathrm{m}^{3}$, respectively. The radon concentration in the building with sealing and energy-saving equipment was found to be 1.5 times higher than the other.

\subsection{Annual Exposure and Effective Dose}

The calculated exposure and annual effective doses for occupants exposed to radon in the indoor air of various indoor environments were highest for the house with $5.608 \mathrm{WLM} / \mathrm{yr}$ and $0.870 \mathrm{mSv} / \mathrm{yr}$, respectively (Table 2). This result seems to be due to the fact that the house has radon concentrations that are higher than other indoor environments and that residents remain in it longer. This suggests that more intensive research is required for the house than for other indoor environments.

The summarized results of the annual exposure and effective doses calculated for residents in each facility were $6.901 \mathrm{WLM} / \mathrm{yr}$ and $1.071 \mathrm{mSv} / \mathrm{yr}$, respectively (Table 2), and this annual effective dose was similar to the 1.0 $\mathrm{mSv} / \mathrm{yr}$ recommended by UNSCEAR (UNSCEAR, 2000).

\section{Discussion}

In many nations throughout the world since the 1970s, many researchers have focused on radon because radon is given more weight in the population's total radiation exposure dose, continuous exposure to radon increases the possibility of developing lung cancer, and radon is difficult to control and manage since it is a naturally-occurring radiation source different from other artificial sources. Therefore, many advanced countries have assessed the annual exposure dose of their citizens to radon and established recommended levels for radon concentrations if required. Each of these countries had executed research on radon concentrations to protect its populace from radon between the 1980s and 1990s (UNSCEAR, 1993). Recently, the World Health Organization (WHO) has performed an assessment of the influence of radon exposure on residents' health and has, furthermore, promoted an international joint study to present a proper control plan and policy to its member countries (Zhanat C, 2005). In contrast, some colleges and institutes in Korea have performed studies on radon concentrations over some locally limited areas, but a general study throughout the country has still not been 
carried out. Therefore, there truly has not been any study to assess the health hazard of inhaled radon and to establish a control plan.

This study has been performed in 2 parts as a way to prepare the foundation for participation in WHO's international joint study. First, the research results of the radon concentrationunder actual conditions in the air in various indoor environments in Korea were collected and re-analyzed and recommendations made. Second, the exposure and effective dose by inhalation of radon in various indoor environments were calculated and reported. However, because studies on radon concentrations in Korea have been executed by few researchers and over limited areas, the results of this study can not represent the overall radon concentration in Korea. It is also difficult to exclude the occurrence of many limitations in calculating the exposure and effective dose due to inhaling radon, based on the the concentration results. Therefore, this study has tried to exclude biases from poor research data by collecting study results partially performed so far, to consider the limitations in many studies, and to decrease the errors in the study results that might be caused by these limitations. To maintain the study's quality, only articles that had been reported in Korean environmentally-related journals were selected and used. And to minimize any uncertainty which might occur in selecting and collecting data from precedent partially-performed studies, only data that conformed to the literature selection standard in screening research data were selected, that is, the results from articles performed with the objective of the studying actual conditions. This study designed the literature selection standard to select only articles that examined the same measurement and analysis, and selected only the study results that conformed to this standard. By applying this standard, the study tried to minimize heterogeneity among studies which might happened when integrating various study results. To minimize biases that might be caused by heterogeneity of the measurement methods, the study used only research data obtained by a solid-state track detector. It was assumed that the solid-state track detector has been widely used internationally to measure the distribution of indoor radon concentrations in each country (Durrani \& Ilić, 2004), and that, because it is not affected as sensitively by a change in radon concentration due to several influence factors over a short time as measurement methods that assess a radon concentration through exposure to radon for a long period, it is a proper method to express the mean radon concentration in the subject facilities under examination. Therefore, the study selected and collected only research data obtained with a solid-state track detector and calculated the pooled average radon concentration. In addition, as a way to reduce uncertainty, which might occur when incorporating study results presented in the selected literature, this study used the reverse-variance-weighted average method considering the size (the number of data points) of each study to increase the accuracy of the calculated pooled average concentration. Regarding those study limitations that might occur regardless of the effort to reduce the limitations in such a study design, first, it was not possible to completely control a sample's representation and an interpretation error of a result due to the sampling error that might occur by not reflecting the whole of the precedent studies' results about the indoor environment in Korea. Second, the study selected research data on the radon concentrations in the indoor air in various indoor environments all over the country, therefore, it could not completely control the error in the data sum that could occur if data were incorporated without consideration of the differences among the study areas such as probable variability in type of soil and the differences among study researchers. However, it examined research data on the radon concentration in various indoor environments in Korea, from studies which had been partially performed, and used these data to show the annual exposure and effective doses to residents in various indoor environments. Therefore, it has significance in securing basic data and preparing a foundation to participate in the international joint studies of WHO and other world-wide radiation-related institutes.

Previous studies have shown that radon pollution originates mainly from soil, therefore, the radon concentrations are high in underground space. Most Korean studies on the radon concentrations in indoor air were found to be focused on houses and subway stations. Lee et al. (2004) suggested that Korean studies related to indoor air in the past had been mainly executed on radon concentrations in the house. Many studies were also carried out on the radon concentration inside subway stations because the subway station is the typical underground building in Korea that is highly likely to have a problem caused by radon, Since 2003, it was found that the scope of research has been extended to other public facilities beside the house and subway station, probably because of the law of indoor air quality control in public facilities by the Ministry of Environment in 2004.

The calculated pooled average radon concentrations in the air of all the subject facilities in Korea were far lower than the $148 \mathrm{~Bq} / \mathrm{m}^{3}$ action level for radon in indoor air recommended by the law covering indoor air quality control in public facilities and the U.S. EPA. In this study, the house was found to have the highest radon concentrations among the subject facilities, and considering that residents stay longer in their houses than other facilities, it is suggested that continued research is required to support persistent maintenance and control of radon. In addition, the subway station is the facility that is representative of an underground environment and 
there have been cases of increased radon concentrations in the air within subway stations because of the occasional inflow of underground water. Therefore, as for the house, continued research is required.

Even though the results of the pooled average radon concentrations did not show much difference between the ground and underground levels of a building, this may be because the radon concentrations were not compared between the ground and underground levels within the same building. When the individual study results, which were used in the calculation of the pooled average, were considered, it was confirmed that the radon concentrations in the underground air is higher than those above ground. Also, the radon concentrations within buildings equipped with tight-sealing and energy-saving equipment to improve energy efficiency were higher than those of buildings not so equipped. Such a result indirectly implies that ventilation inside a building works to lower the radon concentration in the indoor air. Therefore, isolation of the air-flow from underground facilities to the living space above and positive ventilation should be considered as a way to lower the radon concentrations inside a building in the future. In addition, through such a study, it was acknowledged that Korean studies about the factors influencing radon concentrations in indoor air have been executed as one part of partial studies on actual conditions so that there have been no studies to explain the factors that have a large affect on radon concentration when drafting a control plan. Therefore, further studies are required to explain the factors that influence the distribution of indoor radon concentrations and to provide data to be applied in establishing a control plan to lower radon concentrations.

The assessment of the annual effective dose due to inhaling radon in the air of various indoor environments gave a result that was similar to the value of $1.0 \mathrm{mSv} / \mathrm{yr}$ recommended by UNSCEAR (UNSCEAR, 2000), but this value only represents the effective radon exposures in the house, subway station, department store, hospital, office and school, which were the subject facilities of this study, and does not include the effective exposes at other facilities. Therefore, if exposures at other indoor environments are considered, the effective dose might be a little higher than UNSCEAR's recommended annual effective dose, but because the occupants do not stay long at these other facilities, it is not expected not to be much higher. Recently, Korean studies have been extended to various indoor environments including public facilities and it will be possible to secure research data on the radon concentrations in these facilities and to secure additional data about the residents' exposure. These studies can be used in assessing the total effective dose due to people from inhaled radon.

Through performing this study, it was found that the radon-related studies in Korea are not sufficient compared to those in foreign countries and that there has been no epidemic research to explain the occurrence of lung cancer and other physical disorderscaused by inhaled radon. Radon is a naturally occurring radioactive pollutant that always exists in our surroundings. Since this material is a hazardous pollutant causing physical disorders such as lung cancer, it is recommended that additional studies and corresponding political action should be accomplished. To assist in those studies and political action, the government's positive support is required as well as the active involvement of Korean researchers and the government in international joint studies with related institutes world-wide.

\section{References}

Kim, D.S., Kim, Y.S., Kim, S.D., Shin, E.B., Kim, S.C., \& Yoo J.S. (1994). Concentration distributions and a reduction strategy of airborne radon in Seoul Metropolitan subway stations. J. KAPRA, 9, 271-277.

Kim, S.A., \& Paik, N.W. (2002). A Study on indoor radon concentrations in Urban Area. Kor. J. Environ.Heallth Soc., 28, 89-98.

Kim, Y.J., Kim, J.Y., Park, S.Y., \& Sin, D.C. (1999). A study on the indoor radon concentration of elementary schools in Seoul. In: Proceedings of 29th Meeting of KOSAE, 297-298.

Kim, Y.S. (1989). Indoor radon concentrations in the Seoul Area. Kor. J. Environ. Health Soc., 15, 11-18.

Kim, Y.S. (1990). Indoor radon levels in four different areas in Korea. Kor. J. Environ. Health Soc., 16, 1-7.

Kim, Y.S. (1991). Indoor and outdoor radon concentrations in selected homes near nuclear power plants. J. Kor. Public Health Assoc., 17, 60-66.

Kim, Y.S., Kim, H.T, Lee, C.M., Chang, G.S., \& An, J.H. (2000). A Study on distribution of particulate and radon concentrations in indoor envrionment in Seoul city. In: Proceeding of the 31st Meeting of KOSAE, 365-366.

Kim, Y.S, Roh, Y.M., Hong, S.C., Lee, C.M., Jo, J.H., \& Jeon, H.J. (2004). A study on the characteristic of radon in public facilities, In: Proceeding of the 38th Meeting of KOSAE, 505-506. 
Kim, Y.S., Lee, C.M., Kim, H.T., \& Iida T. (2002). A survey of indoor and outdoor radon concentrations by alpha track detector in Korea, Kor. J. Environ. Health, 28, 71-76.

Kim, Y.S., Hong, S.C., Lee, C.M., Park, Y.S., Lee, T.H., Jeon, H.J., \& Jo J.H. (2003). Characterization of Radon Concentration in Public Facilities. In: Proceeding of the 36th Meeting of KOSAE, 529-530.

Kim, Y.S., Kim, J.Y., Park, H.S., Moon, J.Y., Park, S.E., \& Shin, D.C. (2003). "a" A study on multi-media exposure and risk assessment of radon. In: Proceeding of the 35th Meeting of KOSAE, 369-370.

Kim, C.G., Kim, Y.J., Lee, J.S., \& Roh, B.H. (2003). "a" Indoor radon concentrations in house and public buildings. In: Proceeding of the 35th Meeting of KOSAE, 67-68.

Kim, H.G., \& Jeong, K.M. (2006). Variation of seasonal expsoureto $\mathrm{PM}_{2.5}$ and PAHs in homes of Chunchun city, Korea. Kor. J. Environ.Toxicol., 21, 57-69.

Son, H.H. (1998). Meta-analysis method of Medicine, Nurse and Social science. Chungmun Press, 36-52.

Lee, J.D., Kim, Y.S., Son, B.S., \& Kim, D.S. (2006). A study of radon concentration in first floor and basement and prediction of annual exposure rate in Korea. J. Environ. Sci., 15, 311-317.

Lee, C.M., Kim, Y.S., Kim, J.C., \& Jeon H.J. (2004). Distribution of radon concentration at subway station in Seoul. Kor. J. Environ. Health, 30, 469-480.

Lee, C.M., Kim, Y.S., Park, W.S., \& Iida T. (2002). A Survey of indoor and outdoor radon concentrations in five major cities. Kor. J. Hyg., 17, 75-82.

Jeon, J.S., Kim, D.C., Lee, H.C., Lee, J.Y., Hong, D.H., Lee, Y.S., \& Shin, J.S. (2006). A study on assessment of distribution characteristics of ${ }^{222} \mathrm{Rn}$ concentration in Seoul subway stations. In: Proceeding of the 41st Meeting of KOSAE, 549-551.

Chung, H.J., Baek, S.H., \& Kim, J.H. (2001). Radon concentration and prediction of annual exposure rate of underground shopping center in Daejeon area. J. Kor. Soc. Environ. Admin., 7, 219-225.

Ministry of Environment, Korea. (2001). Guide to TLVs.

Anastasiou, T., Tsertosa, H., Christofides, S., \& Christodulides, G. (2003). Indoor Radon (222Rn) concentration measurements in Cyprusundig high-sensitivity portable detectors. J. Environ. Radioactivity, 68, 159-169. http://dx.doi.org/10.1016/S0265-931X(03)00052-3

Bodansky, D. (1989). Indoor radon and its hazards, In: Overview of indoor radon problem, University of Washington Press, Seattle and London, 9-23.

Durrani, S.A. (1999). Radon concentration values in the field: correlation with underlying geology. Radiat. Meas., 31, 271-276. http://dx.doi.org/10.1016/S1350-4487(99)00105-5

Marley, F., \& Phillips, P. S. (2001). Investigation of the potential for radon mitigation by operation of mechanical systems affecting indoor air. $J$. Environ.Radioacivity, 54, 205-219. http://dx.doi.org/10.1016/S0265-931X(00)00091-6

Fovt, L.L., Baixeras, C., Domingo, C., \& Fermandez, F. (1999). Experimental and theoretical study of radon levels and entry mechanism in a Mediterrancean climate house. Radiat. Meas., 31, 277-282. http://dx.doi.org/10.1016/S1350-4487(99)00110-9

International Commission on Radiological Protection (ICRP). (1994). Protection against radon-222 at home and at work. ICRP Publ., 65, Ann. ICRP, 23, 1-38. http://dx.doi.org/10.1016/0146-6453(93)90002-P

Barros-Dios, J.M., RuanoRavina, A., Gastelu-Iturri, J., \& Figueiras, A. (2007). Factors underlying residential radon concentration, results from Galicia, Spain. Environ. Res., 103, 185-190. http://dx.doi.org/10.1016/j.envres.2006.04.008

Lee, S.C., \& Chang, M. (2000). Indoor and outdoor air quality investigation at schools in Hong Kong, Chemosphere, 41, 109-113. http://dx.doi.org/10.1016/S0045-6535(99)00396-3

Li, X., Wang, Y., Zheng, B., \& Wang, X. (2005). A study of reducing radon level by ventilation in underground space. Nucl. Tech., 28, 954-956.

Miles, J. (1988). Development of maps of radon-prone areas using radon measurements in houses. J. Hazard. Mater., 61, 53-58. http://dx.doi.org/10.1016/S0304-3894(98)00107-1

National Radiological Protection Board (NRPB). (1990). Statement by the National Radiological Protection: limitation of human exposure to radon in homes. NRPB Doc., 1, 15-16. 
Robinson, J., \& Nelson, W.C. (1995). National human activity pattern survey data base. Environmental Protection Agency, US. Research Triangle Park, NC.

United Nations Scientific Committee on the Effects of Atomic Radiation (UNSCEAR). (2000). Report to the General Assembly. New York, United Nations.

United Nations Scientific Committee on the Effects of Atomic Radiation (UNSCEAR). (1993). Report to the General Assembly. New York, United Nations.

Environmental Protection Agency, US. (1986). A citizen's guide to radon, Office of air and rdiation, OPA-86-004.

National Research Council, US. (1999). Board on effects of ionizing radiation, VI Report on health effects of exposure to radon. http://www.nap.edu/books/0209056454 /html/index.html

Wood, J.E. (1991). An engineering approach to controlling indoor air quality. Environ. Health Persp., 125, 15-21. http://dx.doi.org/10.1289/ehp.919515

Yang, W., Yang, L., Lu, Y. Liu, H., Lu, S., \& Li, W. (1999). Measuring ${ }^{222}$ Rn level in underground space by SSNTD's. Chinese J. Health, 3, 93-98.

Table 1. A summary of articles on radon surveys in various indoor environments from Korean literature review Unit: $\left(\mathrm{Bq} / \mathrm{m}^{3}\right)$

\begin{tabular}{|c|c|c|c|}
\hline Author (year) & $\begin{array}{c}\text { Indoor environment } \\
\text { sampled (period) }\end{array}$ & Sampling method & Summary (Concentration) \\
\hline $\begin{array}{l}\text { Jeon et al. } \\
(2006)\end{array}$ & $\begin{array}{l}\text { Subway station } \\
(1998 \sim 2004)\end{array}$ & $\alpha$-track detector & $\begin{array}{l}\text { Subway station } \\
\text { Platform ( } n=1325): 67.34 \pm 41.07 \\
\text { Concourse ( } n=1326): 52.17 \pm 31.08 \\
\text { Transform ( } n=279): 71.04 \pm 37.37\end{array}$ \\
\hline $\begin{array}{l}\text { Lee et al. } \\
(2006)\end{array}$ & $\begin{array}{c}\text { House \& Public } \\
\text { facilities } \\
(1996.2 \sim 1997.4)\end{array}$ & $\begin{array}{c}\text { Radon Cup Monitor } \\
\text { (Japan) }\end{array}$ & $\begin{array}{l}\text { Department }(\mathrm{n}=8) \text { : underground }-31.6 \pm 10.2 \\
\text { above ground }-28.2 \pm 8.3 \\
\text { Office }(\mathrm{n}=8) \text { : underground }-53.2 \pm 24.8 \\
\text { above ground }-32.2 \pm 6.2 \\
\text { Apartment }(\mathrm{n}=8) \text { : underground }-24.4 \pm 6.9 \\
\text { above ground }-34.5 \pm 8.5 \\
\text { Hospital }(\mathrm{n}=8) \text { : underground }-29.4 \pm 6.5 \\
\text { above ground }-28.6 \pm 7.4 \\
\text { House ( } \mathrm{n}=8) \text { : underground }-88.6 \pm 50.3 \\
\text { above ground }-50.5 \pm 61.2\end{array}$ \\
\hline $\begin{array}{l}\text { Lee et al. } \\
(2004)\end{array}$ & $\begin{array}{l}\text { Subway station } \\
(1999.1 \sim 5)\end{array}$ & $\begin{array}{l}\text { RadTrack detector } \\
\text { (LANDAUER) } \\
\text { Pylon AB-5 } \\
\text { (PYLON) }\end{array}$ & $\begin{array}{l}\text { RadTrack } \\
\text { Subway station: platform }(n=33)-78.9 \pm 8.55 \\
\text { Concourse }(n=34)-38.2 \pm 4.25 \\
\text { Office }(n=34)-61.8 \pm 5.66 \\
\text { Pylon AB-5 } \\
\text { Subway station (platform) } \\
(n=23)-26.76 \pm 11.00,(n=23)-30.61 \pm 13.53 \\
(n=23)-64.57 \pm 12.52,(n=23)-102.42 \pm 13.47 \\
(n=23)-116.55 \pm 23.93,(n=23)-74.08 \pm 13.07 \\
(n=23)-75.30 \pm 16.69,(n=23)-80.68 \pm 20.72 \\
(n=23)-20.67 \pm 7.73,(n=23)-21.75 \pm 11.60 \\
(n=23)-19.55 \pm 14.68,(n=19)-29.76 \pm 9.75\end{array}$ \\
\hline
\end{tabular}




\begin{tabular}{|c|c|c|c|}
\hline & & & $\begin{array}{l}(n=24)-28.00 \pm 13.28,(n=24)-61.05 \pm 10.99 \\
(n=22)-71.56 \pm 22.36,(n=22)-93.63 \pm 22.01\end{array}$ \\
\hline $\begin{array}{l}\text { Kim et al. } \\
\text { (2004) }\end{array}$ & $\begin{array}{l}\text { Public facilities } \\
(2004.5 \sim 8)\end{array}$ & $\begin{array}{c}\text { RAD-7 } \\
\text { (DURRIDGE) }\end{array}$ & $\begin{array}{l}\text { Subway station ( } \mathrm{n}=16): 26.34 \pm 19.10 \\
22.83 \pm 8.67 \\
\text { Departmentstore }(\mathrm{n}=16): 15.64 \pm 12.31 \\
\text { Library ( } \mathrm{n}=16): 22.20 \pm 8.88 \\
\text { Museum ( } \mathrm{n}=16): 20.43 \pm 11.88 \\
\text { Office ( } \mathrm{n}=16): 17.71 \pm 10.37 \\
\text { Theater ( } \mathrm{n}=16): 25.62 \pm 18.15 \\
\text { Apartment ( } \mathrm{n}=16): 10.24 \pm 6.84 \\
39.72 \pm 23.74 \\
\text { Kindergarten ( } \mathrm{n}=16): 7.68 \pm 3.03 \\
15.36 \pm 6.39\end{array}$ \\
\hline $\begin{array}{l}\text { Kim et al. } \\
\text { (2003) }\end{array}$ & $\begin{array}{c}\text { House \& Public } \\
\text { facilities } \\
(2002.12 \sim 2003.3)\end{array}$ & $\begin{array}{c}\text { RadTrack detector } \\
\text { (LANDAUER) }\end{array}$ & $\begin{array}{l}\text { Office: 109, Hospital-1: 51, Hospital-2: 184, } \\
\text { Subway station: 19, Bus station: 18, } \\
\text { Theater: 27, Library: 13, Museum: 55, } \\
\text { Kindergarten-1: 60, Kindergarten-2: 35, } \\
\text { House: } 34 \text {, Apartment: } 88\end{array}$ \\
\hline $\begin{array}{l}\text { Kim et al. } \\
\text { (2003) }\end{array}$ & $\begin{array}{l}\text { House \& Public } \\
\quad \text { facilities } \\
(2000.1 \sim 12)\end{array}$ & $\begin{array}{l}\text { RadTrack detector } \\
\text { (LANDAUER) }\end{array}$ & $\begin{array}{l}\text { House ( } n=2,500): 53.4 \pm 57.5 \\
\text { Public Facilities }(n=500): 41.0 \pm 26.8\end{array}$ \\
\hline $\begin{array}{l}\text { Kim et al. } \\
\text { (2003) }\end{array}$ & $\begin{array}{c}\text { House } \\
(2000.10,2001.4, \\
2001.9)\end{array}$ & $\begin{array}{c}\text { Electret Passive } \\
\text { Environment Radon } \\
\text { Monitor }\end{array}$ & $\begin{array}{l}\text { Chungbuk ( } n=15): 155.4 \pm 92.5 \\
\text { Daejun }(n=24): 159.1 \pm 66.6 \\
\text { Jeju }(n=15): 85.1 \pm 37.0\end{array}$ \\
\hline $\begin{array}{c}\text { Kim and Paik } \\
\text { (2002) }\end{array}$ & $\begin{array}{c}\text { House, Public facilities } \\
\text { \& School } \\
(1999.8 \sim 11)\end{array}$ & $\begin{array}{c}\text { Electret Passive } \\
\text { Environment Radon } \\
\text { Monitor }\end{array}$ & $\begin{array}{l}\text { Hospital }(\mathrm{n}=3) \text { : underground }-40.6 \pm 19.8 \\
\text { above ground }-44.8 \pm 18.5 \\
\text { Hotel }(\mathrm{n}=2) \text { : underground }-54.1 \pm 36.9 \\
\text { above ground }-43.6 \pm 13.1 \\
\text { Departmentstore }(\mathrm{n}=2) \text { : underground }-29.3 \pm 16.2 \\
\text { above ground }-13.3 \pm 16.2 \\
\text { House ( } \mathrm{n}=6) \text { : underground }-75.8 \pm 33.6 \\
\text { above ground }-39.8 \pm 26.4 \\
\text { School ( } \mathrm{n}=1) \text { : underground }-128.5 \pm 37.3 \\
\text { above ground }-40.8 \pm 4.6\end{array}$ \\
\hline $\begin{array}{l}\text { Lee et al. } \\
\text { (2002) }\end{array}$ & $\begin{array}{l}\text { School (University) } \\
\qquad \begin{array}{l}(19962 \sim 12) \\
(19981 \sim 12)\end{array}\end{array}$ & $\begin{array}{l}\text { EIRM (Model A: } \\
\text { Aloka Gs-201) }\end{array}$ & $\begin{array}{l}1996 \\
\text { Seoul }(n=4): 30.6 \pm 6.9 \\
\text { Daegu }(n=2): 8.0 \\
\text { Daejon }(n=4): 37.4 \pm 6.9 \\
\text { Kwangju (n=2): } 20.8 \\
\text { Busan (n=2): } 12.8 \\
1998 \\
\text { Seoul }(n=4): 26.8 \pm 7.0\end{array}$ \\
\hline
\end{tabular}




\begin{tabular}{|c|c|c|c|}
\hline & & & $\begin{array}{l}\text { Daegu }(n=2): 28.2 \\
\text { Daejon }(n=4): 22.3 \pm 7.9 \\
\text { Kwangju }(n=4): 16.0 \pm 8.0 \\
\text { Busan }(n=4): 10.6 \pm 2.3\end{array}$ \\
\hline $\begin{array}{l}\text { Kim et al. } \\
(2002)\end{array}$ & $\begin{array}{c}\text { School (University), } \\
\text { Public facilities \& } \\
\text { House } \\
(1996.2 \sim 1997.3)\end{array}$ & $\begin{array}{l}\text { EIRM (Model A: } \\
\text { Aloka Gs-201) }\end{array}$ & $\begin{array}{l}\text { School (University) } \\
\text { Seoul }(n=6): 29.0 \pm 12.3 \\
\text { Daegu }(n=4): 19.8 \pm 12.9 \\
\text { Daejon }(n=5): 37.6 \pm 5.4 \\
\text { Kwangju (n=4): } 23.3 \pm 3.9 \\
\text { Busan ( }=4): 10.8 \pm 2.5 \\
\text { Departmentstore }(n=5): 28.2 \pm 9.6 \\
\text { Office ( } n=5): 32.2 \pm 7.1 \\
\text { Hospital }(n=5): 28.6 \pm 8.5 \\
\text { House }(n=5): 50.5 \pm 70.7\end{array}$ \\
\hline $\begin{array}{l}\text { Chung et al. } \\
\text { (2001) }\end{array}$ & $\begin{array}{l}\text { Underground store } \\
\qquad(1999.1 \sim 3)\end{array}$ & $\begin{array}{c}\text { RadTrack detector } \\
\text { (LANDAUER) }\end{array}$ & Underground store $(n=16): 16.65 \pm 4.81$ \\
\hline $\begin{array}{l}\text { Kim et al. } \\
(2000)\end{array}$ & $\begin{array}{l}\text { House \& School } \\
\qquad(2000.6 \sim 9)\end{array}$ & $\begin{array}{c}\text { RAD-7 } \\
\text { (DURRIDGE) }\end{array}$ & $\begin{array}{l}\text { School: } 17.76 \pm 11.47 \\
\text { House: underground }-79.92 \pm 48.10 \\
\text { above ground }-35.15 \pm 23.31\end{array}$ \\
\hline $\begin{array}{l}\text { Kim et al. } \\
\text { (1999) }\end{array}$ & $\begin{array}{c}\text { School } \\
(1999.4 \sim 5)\end{array}$ & $\begin{array}{c}\text { AlphaGUARD PQ } \\
\text { 2000Pro (Genitorn } \\
\text { Co) }\end{array}$ & $\begin{array}{l}\text { School } \\
\text { Construction }(n=2470): 42.032 \pm 35.779 \\
\text { non-construction }(n=2107): 24.790 \pm 18.278 \\
\text { gneiss }(n=2043): 35.113 \pm 26.233 \\
\text { granite }(n=1687): 38.850 \pm 38.036\end{array}$ \\
\hline $\begin{array}{l}\text { Kim et al. } \\
\text { (1994) }\end{array}$ & $\begin{array}{l}\text { Subway station } \\
(1991.10 \sim 11)\end{array}$ & $\begin{array}{c}\text { CRM-510 } \\
\text { (Femto-Tech) }\end{array}$ & $\begin{array}{l}\text { Subway station } \\
\text { exhaust on, make-up on }(n=5): 327.45 \pm 107.67 \\
\text { exhaust off, make-up on }(n=5): 205.35 \pm 38.11 \\
\text { exhaust on, make-up off }(n=5): 333.00 \pm 28.12 \\
\text { exhaust off, make-up off }(n=5): 233.10 \pm 37.74\end{array}$ \\
\hline Kim & $\begin{array}{c}\text { House } \\
(1990.11 \sim 1991.2)\end{array}$ & $\begin{array}{l}\text { Track Etch Radon } \\
\text { Monitor (Tarradex) }\end{array}$ & $\begin{array}{l}\text { Yeongkwang }(n=16): 102.12 \pm 29.97 \\
\text { Uljin }(n=20): 58.09 \pm 29.97\end{array}$ \\
\hline $\begin{array}{c}\text { Kim } \\
(1990)\end{array}$ & $\begin{array}{c}\text { House } \\
(1988.12 \sim 1989.4)\end{array}$ & $\begin{array}{l}\text { Track Etch Radon } \\
\text { Monitor (Tarradex) }\end{array}$ & $\begin{array}{l}\text { Seoul } \\
\text { Underground }(n=8): 125.8 \pm 27.38 \\
\text { above ground }(n=8): 100.64 \pm 34.78 \\
\text { bathroom }(n=12): 98.42 \pm 26.64 \\
\text { kitchen }(n=12): 79.92 \pm 35.15 \\
\text { living room }(n=12): 100.27 \pm 19.98 \\
\text { energy-efficient }(n=7): 122.47 \pm 65.86 \\
\text { non-energy-efficient }(n=9): 85.47 \pm 24.79 \\
\text { Songtan } \\
\text { Underground }(n=6): 156.51 \pm 93.24 \\
\text { above ground }(n=6): 103.97 \pm 66.23\end{array}$ \\
\hline
\end{tabular}




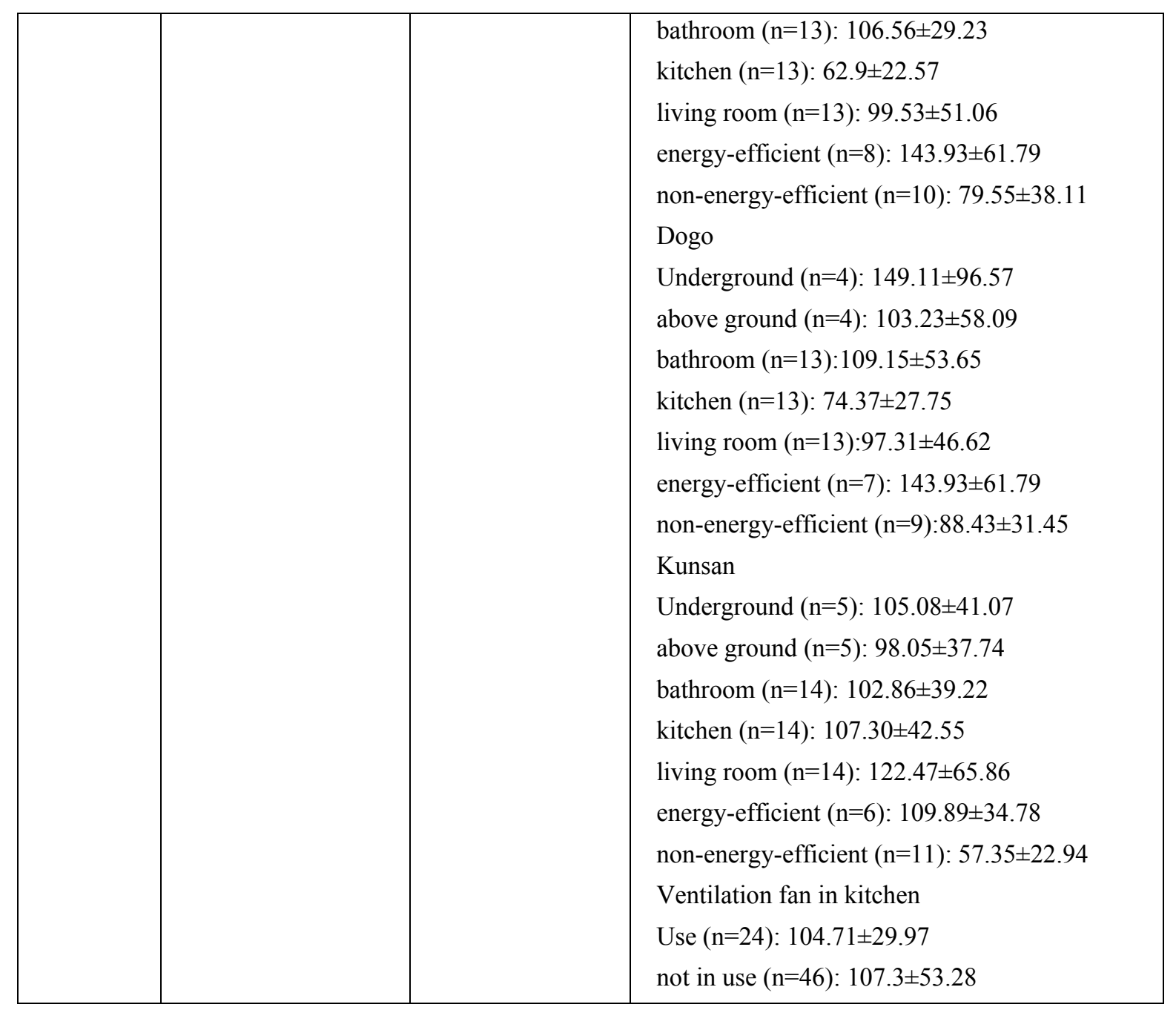

Table 1 is the summary of these 17 study results. Figure 1 shows how frequently studies on indoor radon concentrations were performed for each of the various indoor environments. Houses (including 3 apartments) were found to be studied most frequently with 12 cases $(24.5 \%)$, next were subway stations with 6 cases $(12.2 \%)$, and schools and hospitals with 4 cases $(8.2 \%)$. Research on other public facilities has been executed since 2003 .

Table 2. Annual exposure and effective doses of radon received by inhabitants in various indoor environments

\begin{tabular}{ccccccc}
\hline \multirow{2}{*}{ Facility } & $\begin{array}{c}\text { Exposure time } \\
(\mathrm{min} / \text { day })\end{array}$ & \multicolumn{3}{c}{ Exposure dose } & & Effective dose \\
\cline { 3 - 5 } & & $(\mathrm{WL})$ & $(\mathrm{WLM})$ & $(\mathrm{WLM} / \mathrm{yr})$ & & $(\mathrm{mSv} / \mathrm{yr})$ \\
\hline Department store & 5.62 & 0.136 & 0.002 & 0.027 & & 0.004 \\
Hospital & 13.48 & 0.107 & 0.004 & 0.051 & & 0.008 \\
Total & 1117.93 & 0.827 & 0.575 & 6.901 & & 1.071 \\
\hline
\end{tabular}

The calculated exposure and annual effective doses for occupants exposed to radon in the indoor air of various indoor environments were highest for the house with $5.608 \mathrm{WLM} / \mathrm{yr}$ and $0.870 \mathrm{mSv} / \mathrm{yr}$, respectively (Table 2). This result seems to be due to the fact that the house has radon concentrations that are higher than other indoor environments and that residents remain in it longer. This suggests that more intensive research is required for the house than for other indoor environments.

The summarized results of the annual exposure and effective doses calculated for residents in each facility were 6.901 WLM/yr and $1.071 \mathrm{mSv} / \mathrm{yr}$, respectively (Table 2), and this annual effective dose was similar to the 1.0 $\mathrm{mSv} / \mathrm{yr}$ recommended by UNSCEAR (UNSCEAR, 2000). 


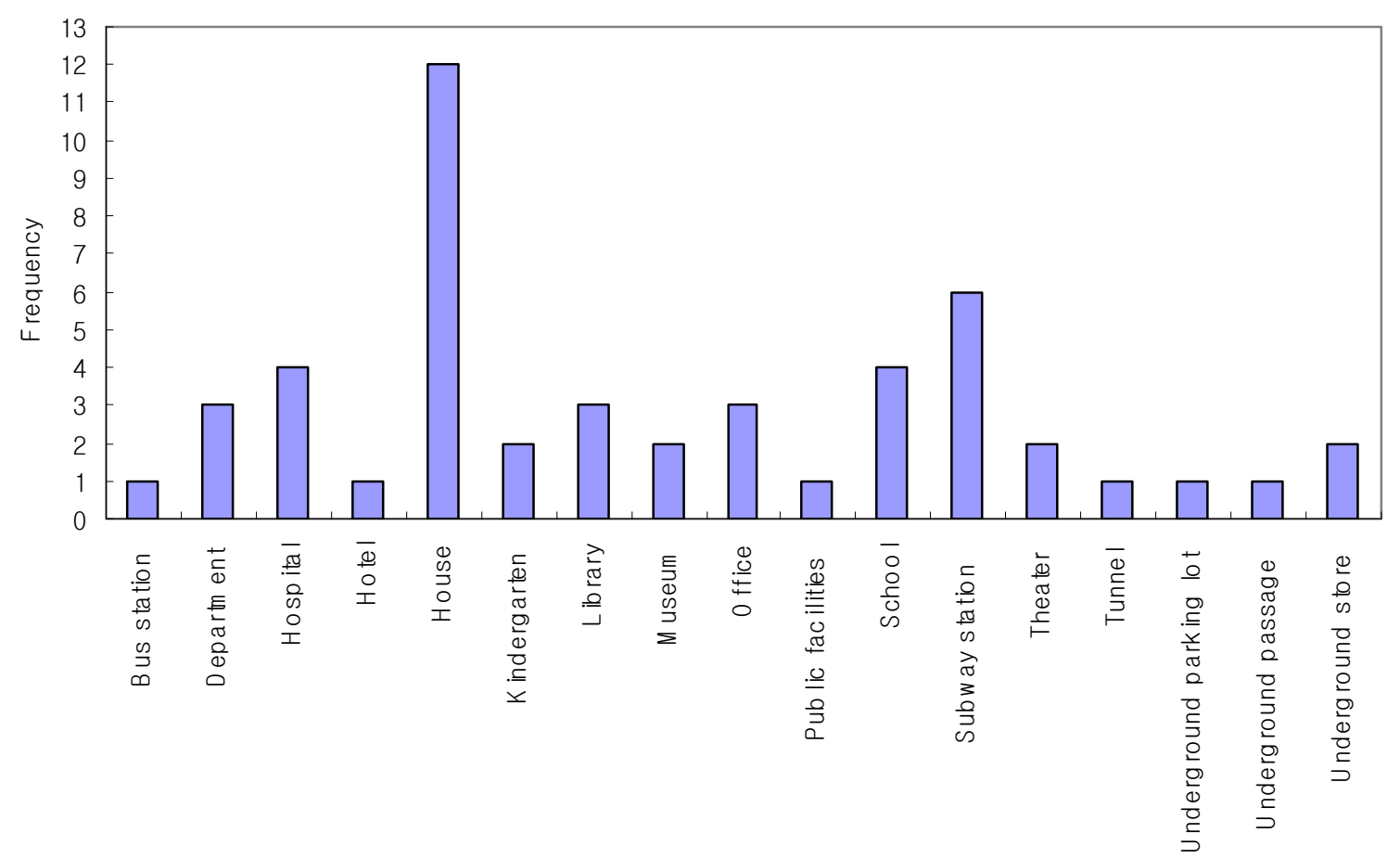

Fac ility

Figure 1. Frequencies of each facility appeared in published radon related papers in Korea

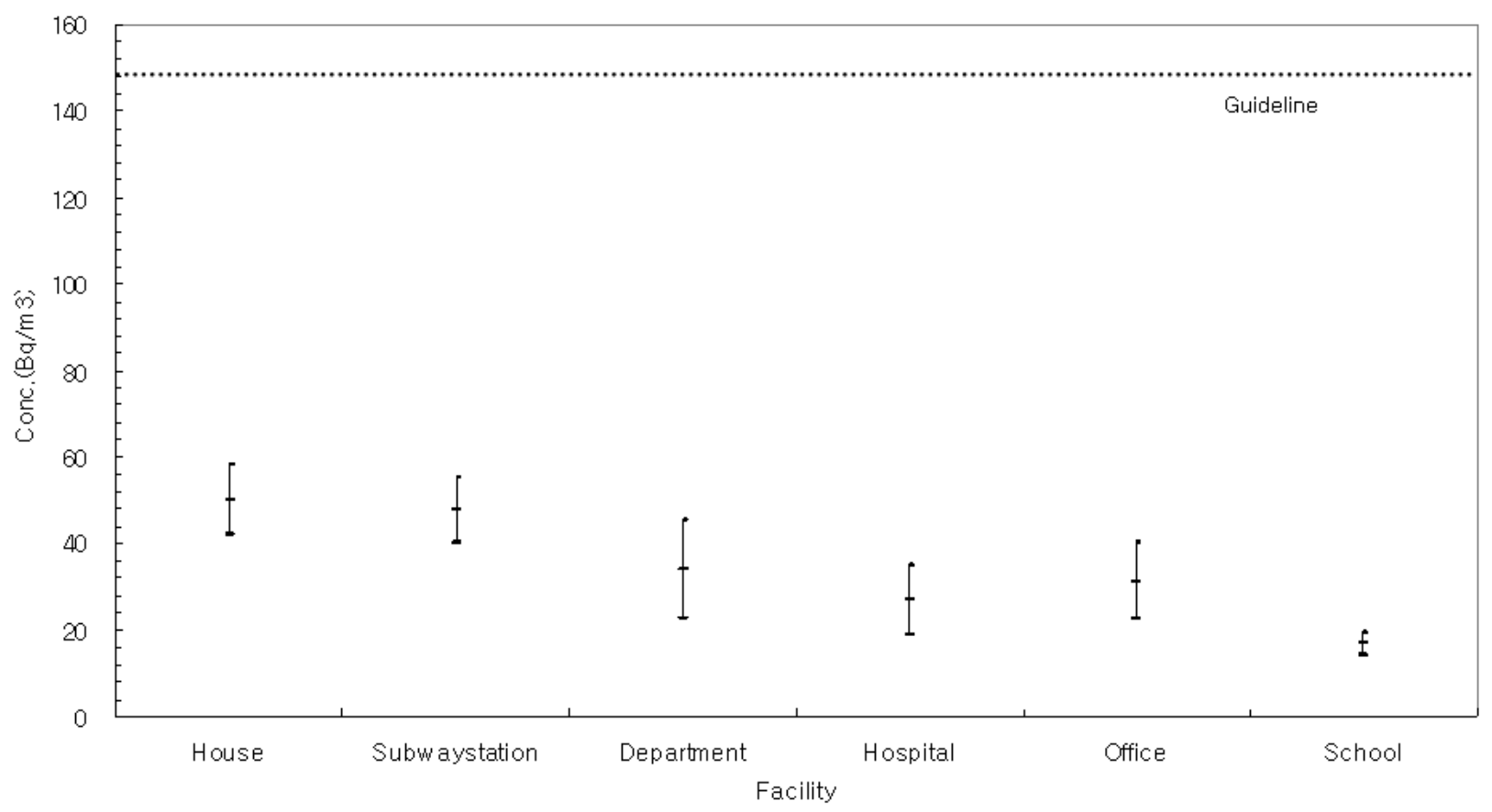

Figure 2. Distribution for pooled concentration of radon in various indoor environment 


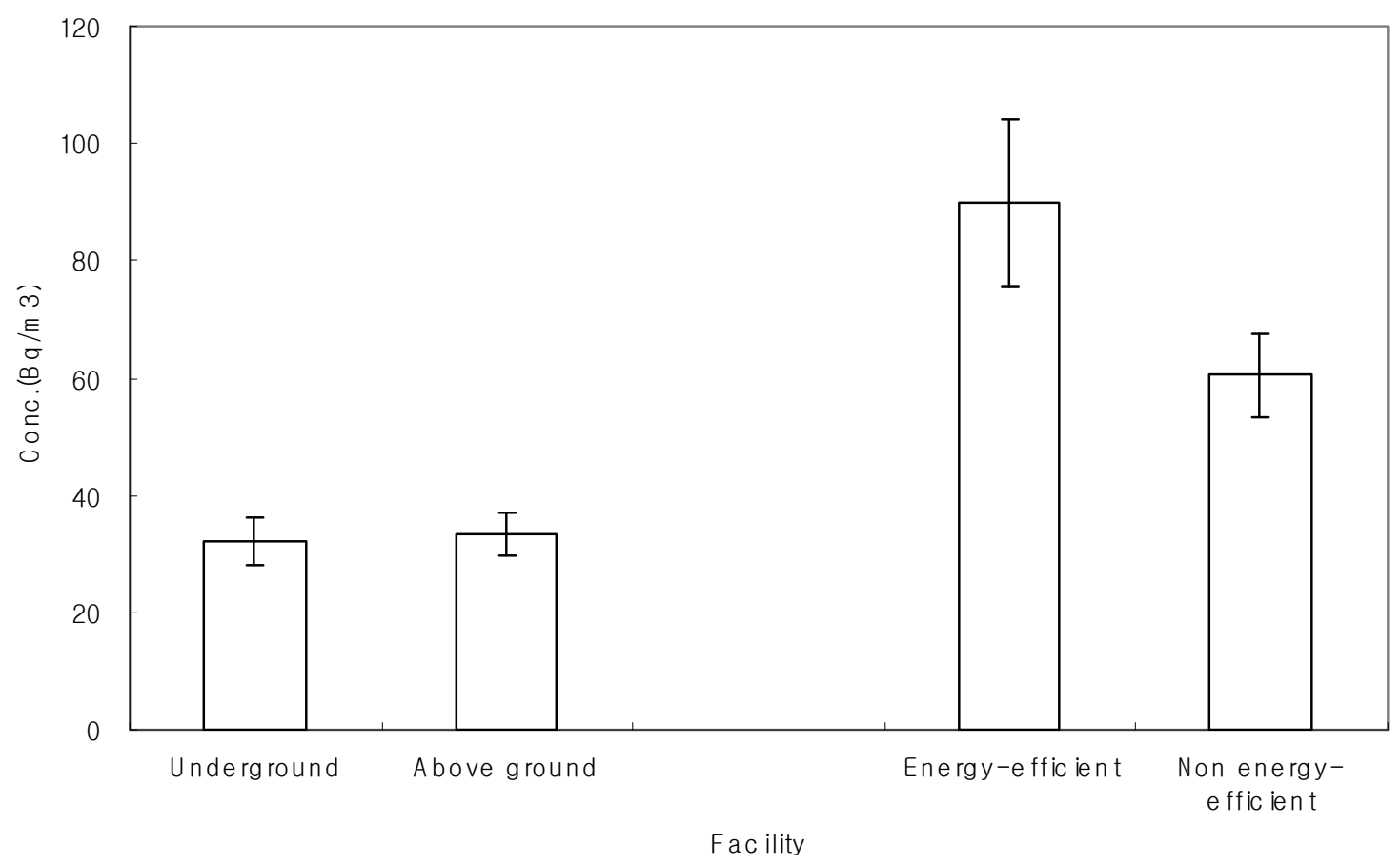

Figure 3. Comparison of pooled concentration of radon by location and type of facility 